\title{
Sistem Pendukung Keputusan untuk Menentukan Tingkat Kelayakan Barang Lelang pada Kejaksaan Negeri Simalungun Menggunakan Metode PROMETHE
}

\author{
Sri Kumala Sari ${ }^{1}$, Jaya Tata Hardinata ${ }^{2}$, M.Fauzan ${ }^{3}$ \\ STIKOM Tunas Bangsa, Pematangsiantar \\ smala6224@gmail.com, jayatatahardinata@gmail.com,mfauzan57@yahoo.com
}

\begin{abstract}
Auctions that use in reality many collateral objects that are not taken by the owner of the goods, the seizure of evidence related to a crime often does not take into account the effects that arise, even though legally the types of objects to be confiscated have different ways and consequences. The basic principles and legal construction of foreclosures are often not comprehensively understood by investigators, including by public prosecutors and judges, in addition to especially in relation to efforts to prove a criminal case in court. So the author conducted a study aimed at providing an alternative Decision Support System for Determining the Feasibility of Goods Auction at the Simalungun District Prosecutor's Office, in the process of this research using the PROMETHE Method (Preference Ranking Organiztion Method For Enrichment Evalution). The purpose of this study is to determine the legal certainty of the auction process and what legal efforts can be carried out by the level of auction feasibility in criminal cases. The results of the crackdown obtained in the feasibility of the auctioned goods are Honda Cs1, Honda bead, Honda bead hitam, Honda vario, Yamaha RX king.
\end{abstract}

Keywords : Decision Support System, Prometh, Auction, simalungun state prosecutor's office

Abstrak- Pelelangan yang menggunakan dalam kenyataannya banyak benda jaminan yang tidak diambil oleh pemilik barang, Penyitaan suatu barang bukti terkait tindak pidana sering kali tidak memperhitungkan dampak yang timbul, padahal secara hukum jenis benda yang akan disita memiliki cara dan konsekuensi yang berbeda-beda. Prinsip dasar dan konstruksi hukum penyitaan seringkali tidak dipahami secara komprehensif oleh penyidik, termasuk juga oleh Penuntut umum dan hakim, selain terutama dalam kaitannya dengan upaya pembuktian suatu perkara tindak pidana di pengadilan. Maka penulis melakukan penelitian yang bertujuan agar dapat memberikan alternatif Sistem Pendukung Keputusan Untuk Menentukan Tingkat Kelayakan Barang Lelang pada Kejaksaan Negeri Simalungun, Dalam proses penelitian ini menggunakan Metode PROMETHE (Preference Ranking Organiztion Method For Enrichment Evalution). Tujuan penelitian ini untuk mengetahui kepastian hukum terhadap proses lelang dan upaya hukum apa yang dapat dilakukam oleh tingkat kelayakan lelang dalam perkara pidana. Hasil perengkingan yang diperoleh dalam kelayakan barang lelang adalah Honda Cs1, Honda bead, Honda bead hitam, Honda vario, Yamaha RX king.

Kata Kunci : Sistem Pendukung Keputusan, Promethe, Lelang, Kejaksaan Negeri Simalungun 


\section{PENDAHULUAN}

Seiring perkembangan zaman banyak perubahan teknologi dan informasi. Peranan komputer saat ini sangat membantu pekerjaan manusia sehingga lebih cepat untuk mengenali berbagai aspek. Sistem pendukung keputusan bisa digunakan untuk menentukan sebuah keputusan terhadap suatu hal [1]-[11]. Salah satu sistem pendukung keputusan yang bisa digunakan untuk mengambil keputusan adalah metode promethe. Salah satunya sistem pendukung keputusan untuk menentukan tingkat kelayakan barang lelang. Barang lelang atau barang sitaan adalah melakukan pengolahan barang bukti atau barang sitaan yang berasal dari tindak pidana umum atau pidana khusus.

\section{METODOLOGI PENELITIAN}

Sistem Pendukung Keputusan merupakan suatu sistem interaktif yang mendukung keputusan dalam proses pengambilan keputusan melalui alternatifalternatif yang diperoleh dari hasil pengolahan data, informasi dan rancangan model [12].Promethee adalah salah satu metode penentuan urutan atau prioritas dalam analisis multikriteria atau MCDM (Multi Criterion Decision Making). Promethee berfungsi untuk mengolah data, baik data kuantitatif dan kualitatif sekaligus. Dimana semua data digabung menjadi satu dengan bobot penilaian yang telah diperoleh melalui penilaian atau survey [13].Membangun hubungan outranking dari K. Masalah pembuatan keputusan dengan multikriteria dapat dituliskan sebagai berikut :

$\operatorname{Max}\{\mathrm{f} 1(\mathrm{x}), \mathrm{f} 2(\mathrm{x}), \mathrm{f} 3(\mathrm{x}), \ldots, \mathrm{fj}(\mathrm{x}), \ldots ., \mathrm{fk}(\mathrm{x}): \mathrm{x} R\}$

Penulisan multikriterian tersebut menjelaskan nilai hubungan outranking dalam Promethee dengan menjelasan rumus sebagai berikut: Nilai f merupakan nilai nyata dari suatu criteria : $\mathrm{f}$ : $\mathrm{K}$ R untuk setiap alternative a ? $\mathrm{K}$, $\mathrm{f}$ (a) merupakan evaluasi dari alternative tersebut untuk suatu kriteria.

a. Kriteria biasa (Usual Criterion)

Pada referensi ini, tidak ada beda antara a dan $b$ jika hanya jika $f(a)=f(b)$, apabila nilai kriteria pada masing-masing alternatif memiliki nilai berbeda, pembuat keputusan membuat preferensi mutlak untuk alternatif memiliki nilai yang lebih baik.

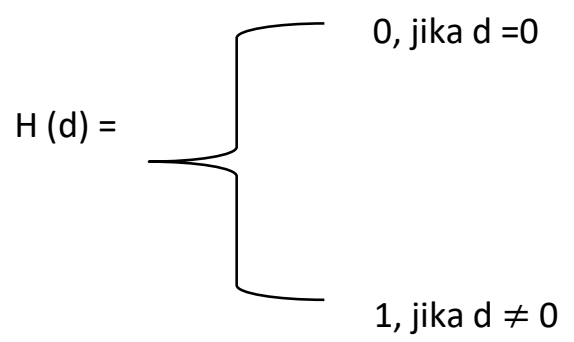

Dimana $\mathrm{d}=$ selisih nilai kriteria $\{\mathrm{d}=\mathrm{f}(\mathrm{a})-\mathrm{f}(\mathrm{b})$

Keterangan:

1. $H(d)$ : fungsi selisih kriteria alternatif 
2. $\mathrm{d}$ : selisih nilai kriteria $\{\mathrm{d}=\mathrm{f}(\mathrm{a})-\mathrm{f}(\mathrm{b})\}[14]$

Pada kasus ini, tidak ada beda (sama penting) antara a dan b jika dan hanya jika(a) = $\mathrm{f}(\mathrm{b})$; Fungsi $\mathrm{H}(\mathrm{d})$ untuk preferensi ini disajikan:

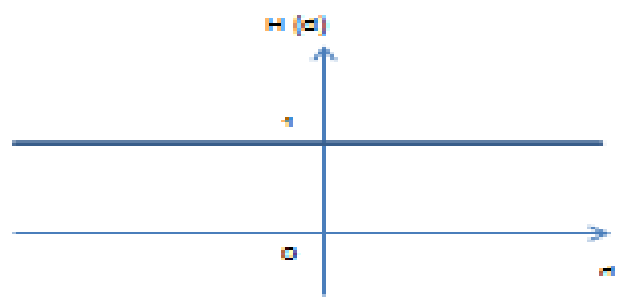

Gambar 1. Kriteria Biasa

b. Kriteria Quasi (Quasi Criterion)

Dalam fungsi preferensi quasi criterion atau kriteria quasi, selisih hasil evaluasi untuk masing-masing nilai kriteria antar alternatif $H$ (d) berpreferensi mutlak jika nilai $\mathrm{H}(\mathrm{d})$ dapat melebihi nilai q.

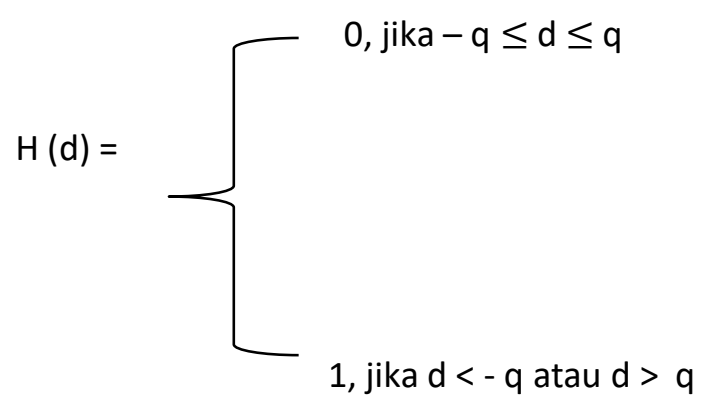

Keterangan:

1. H (d): fungsi selisih kriteria antar alternatif

2. D: selisih nilai kriteria $\{\mathrm{d}=\mathrm{f}(\mathrm{a})-\mathrm{f}(\mathrm{b})\}$

3. Parameter (q): harus merupakan nilai tetap

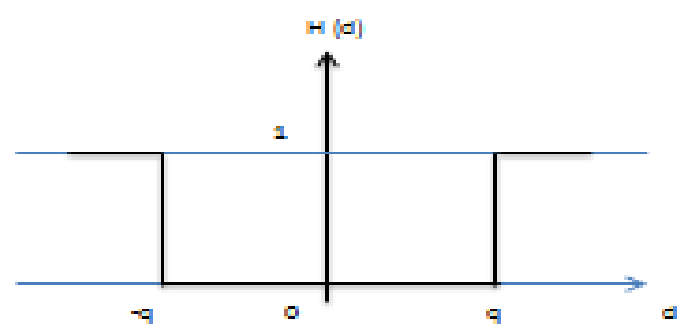

Gambar 2. Kriteria Quasi

Gambar ini menjelaskan dua alternatif memiliki preferensi yang sama penting selama selisih atau nilai $\mathrm{H}$ (d) dari masing-masing alternatif untuk kriteria tertentu tidak melebihi nilai q, dan apabila selisih hasil evaluasi untuk masingmasing alternatif melebihi nilai q maka terjadi bentuk preferensi mutlak.

c. Kriteria dengan Preferensi Linier 
Kriteria preferensi linier dapat menjelaskan bahwa selama ini selisih memiliki nilai yang lebih rendah dari $\mathrm{P}$, preferensi dari pembuat keputusan meningkat linier dengan nilai d.

$$
H(d)=\left\{\begin{array}{l}
d / p \quad=j i k a-p \leq d \leq p \\
1=\text { jika } d<-p \text { atau } d>p
\end{array}\right.
$$

Keterangan:

1. $H(d)$ : fungsi selisih kriteria antar alternatif

2. $\mathrm{d}$ : selisih nilai kriteria $\{\mathrm{d}=\mathrm{f}(\mathrm{a})-\mathrm{f}(\mathrm{b})\}$

3. p: nilai kecenderungan atas.v

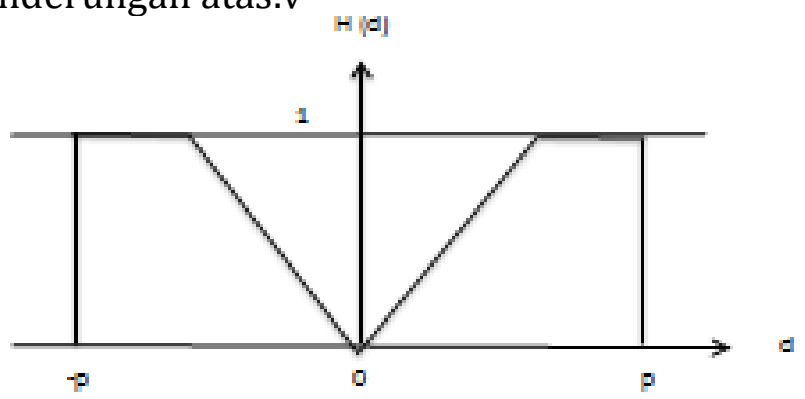

Gambar 3. Kriteria dengan Preferensi Linier

d. Kriteria Level

Dalam kasus ini kecenderungan tidak berbeda dengan q dan kecenderungan peferensi $p$ ditentukan secara simultan. Jika $d$ berbeda diantara nilai $p$ dan $q$, hal ini berarti situasi preferensi yang lemah $(\mathrm{H}(\mathrm{d})=0.5)$.

Fungsi ini disajikan pada:

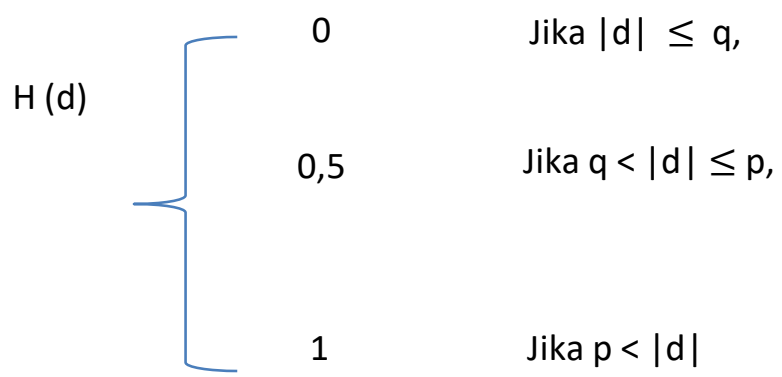

Keterangan:

1. $H(d)$ : fungsi selisih kriteria antar alternatif

2. P: nilai kecenderungan atas

3. Parameter (q): harus merupakan nilai tetap 


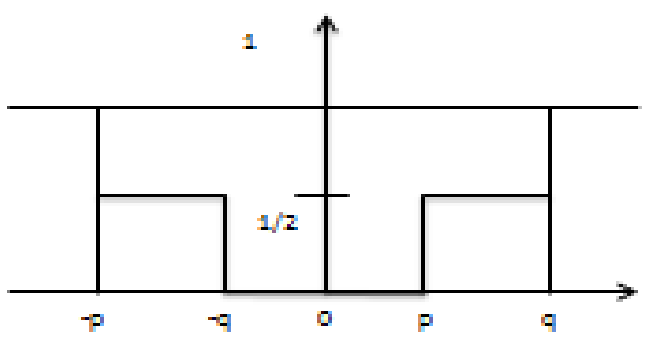

Gambar 4. Kriteria Level

e. Kriteria dengan Preferensi Linier dan Area yang Tidak Berbeda

Pada kasus ini, pengambilan keputusan mempertimbangkan peningkatan preferensi secara linier dari tidak berbeda hingga preferensi mutlak dalam area antara dua kecenderungan $\mathrm{q}$ dan $\mathrm{p}$.

$$
H(d)=\left\{\begin{array}{cl}
0 & \text { jika }|d| \leq q \\
(|d|-q /(p-q) & \text { Jika } q<|d| \leq p+q \\
1 & \text { Jika } p<|d|
\end{array}\right.
$$

Keterangan:

1. H(d): fungsi selisih kriteria antar alternatif

2. $\mathrm{d}$ : selisih nilai kriteria $\{\mathrm{d}=\mathrm{f}(\mathrm{a})-\mathrm{f}(\mathrm{b})\}$

3. Parameter (p): nilai kecenderungan atas 4. Parameter (q): harus merupakan nilai yang tetap.

Dua parameter $\mathrm{p}$ dan $\mathrm{q}$ telah ditentukan nilainya. Fungsi $\mathrm{H}$ adalah hasil perbandingan antar alternatif.

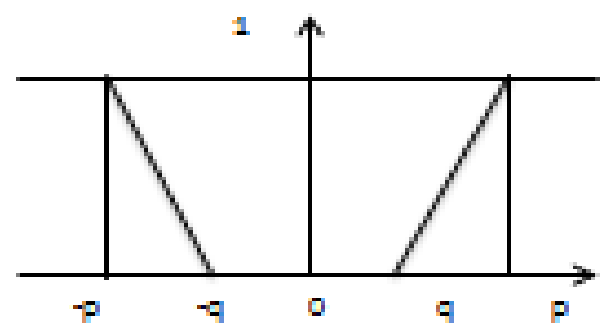

Gambar 5. Kriteria Preferensi Linier dan Area yang Tidak Berbeda

\section{f. Kriteria Gaussian}

Fungsi ini bersyarat apabila telah ditentukan nilai g, dimana dapat dibuat berdasarkan distribusi normal dalam statistik. Nilai $H(d)$ tidak akan pernah bernilai satu. $H(d)=1-\exp \{-d 2 / 2$ ??2 $\}$ Pada penerapannya kriteria Gaussian akan digunakan pada distribusi normal statistik seperti penilaian terhadap 
tingkat keamanan lingkungan. Nilai g merupakan batas antara keamanan buruk sampai dengan tingkat aman sekali. Pada kriteria Gaussian tidak ada parameter yang tetap dalam menentukan nilai batas parameter $(\mathrm{g})$.

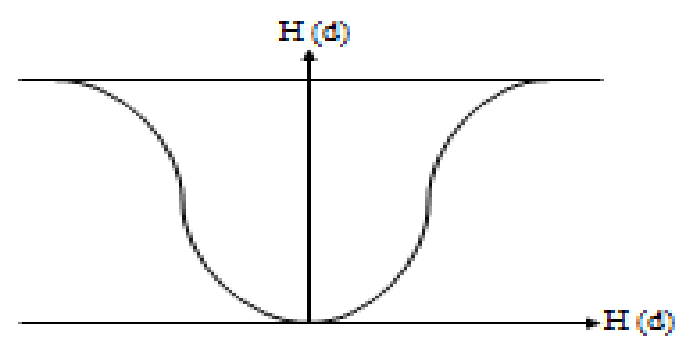

Gambar 6. Kriteria Gaussian

g. Indeks preferensi multikriterian

indeks preferensi multikriteria ditentukan berdasarkan nilai rata-rata bobot dari fungsi preferensi pi.

$\varphi(a, b)=\sum_{i=1}^{n} \quad \pi_{i} P_{I}(a, b): \forall a, b \in A$

yang merupakan intensitas preferensi pembuat keputusan yang menyatakan bahwa alternative a lebih baik dari alternative $b$ dengan pertimbangan secara simultan dari seluruh kriteria. Hal ini dapat disajikan dengan nilai antara nilai 0 dan 1, dengan ketentuan sebagai berikut :

1. $\varphi(1 a, b)=0$ menunjukan preferensi yang lemah untuk alternative $a>$ alternative $b$ berdasarkan semua criteria.

2. $\varphi(a, b)=1$ menunjukan preferensi yang kuat untuk alternative $a>$ alternative $b$

Metode penelitian adalah rangkaian cara terstruktur atau sistematis yang digunakan oleh para peneliti dengan tujuan mendapatkan jawaban yang tepat atas apa yang menjadi pertanyaan pada objek penelitian. Atau secara mudahnya arti metode penelitian adalah upaya untuk mengetahui sesuatu dengan rangkaian sistematis.

h. Metode Pengumpulan Data

Pengumpulan data merupakan proses pengadaan data primer, untuk kebutuhan suatu penelitian. Adapun teknik pengumpulan data dalam penelitian ini yaitu :

1. Penelitian Kepustakaan (Library Research) yaitu memanfaatkan perpustakaan sebagai sarana dalam mengumpulkan data, dengan mempelajari buku - buku sebagai bahan referensi. Hal ini dilakukan dengan membaca tulisan berupa buku dan jurnal yang berkaitan dengan kasus yang penulis angkat.

2. Penelitian Lapangan (Field Work Research) yaitu penelitian yang dilakukan secara langsung dilapangan dengan menggunakan beberapa teknik sebagai berikut:

a. Observasi adalah metode pengumpulan data dengan cara mengadakan pengamatan langsung terhadap berbagai kegiatan yang ada. Hal ini penulis 
lakukan dengan melakukan pengamatan langsung di lokasi penelitian guna mencari data-data yang diperlukan dalam penelitian ini seperti pengambilan sample alternatif dan kriteria penilaian yang akan diuji.

b. Wawancara adalah proses pengumpulan data atau informasi melalui tatap muka antara pihak penanya (interviewer) dengan pihak yang ditanya atau penjawab (interviewee). Hal ini penulis lakukan dengan bertanya langsung kepada pihak-pihak terkait serta yang bertanggung jawab dalam mengecek kelayakab barang lelang pada kantor kejaksaan negeri simalungun.

c. Dokumentasi adalah pengumpulan data yang dilakukan untuk mendapatkan data sekunder dari dokumen-dokumen atau arsip-arsip, yang relavan dengan penelitian ini. Hal ini penulis lakukan dengan membuat dokumen penilaian sample alternatif terhadap kriteria yang sebelumnya telah didiskusikan saat sesi wawancara.

i. Analisis Data

Data yang digunakan berupa data kriteria dengan pembobotan sesuai dengan rating kepentingannya. Data kriteria yang digunakan dalam menentukan Tingkat Kelayakan Barang Lelang pada Kejaksaaan Negeri Simalungun.

Tabel 1. Data Kriteria

\begin{tabular}{|l|l|l|}
\hline No & \multicolumn{2}{|c|}{ Kriteria } \\
\hline 1 & $\mathrm{C}_{1}$ & BPKB \\
\hline 2 & $\mathrm{C}_{2}$ & STNK \\
\hline 3 & $\mathrm{C}_{3}$ & PAJAK \\
\hline 4 & $\mathrm{C}_{4}$ & MESIN \\
\hline 5 & $\mathrm{C}_{5}$ & LAMA PEMAKAIAN \\
\hline
\end{tabular}

Tabel 2. Tingkat Kepentingan

\begin{tabular}{|l|l|l|}
\hline \multicolumn{3}{|c|}{ Keterangan Rank Kepentingan } \\
\hline \multicolumn{2}{|c|}{ BPKB } & STNK \\
\hline No & Keterangan & Bobot \\
\hline 1 & Ada & 5 \\
\hline 2 & Tidak Ada & 2 \\
\hline \multicolumn{3}{|c|}{ Pajak } \\
\hline No & Keterangan & Bobot \\
\hline 1 & Hidup & 5 \\
\hline 2 & Mati & 2 \\
\hline \multicolumn{3}{|c|}{ Mesin } \\
\hline No & Keterangan & Bobot \\
\hline 1 & Original & 5 \\
\hline 2 & Tidak Original & 2 \\
\hline
\end{tabular}

Table 3. Lama Pemakaian

\begin{tabular}{|l|l|l|}
\hline \multicolumn{3}{|c|}{ Lama Pemakaian } \\
\hline No & Keterangan (Tahun) & Bobot \\
\hline 1 & $1-5$ & 5 \\
\hline 2 & $6-10$ & 3 \\
\hline 3 & $11-15$ & 1 \\
\hline
\end{tabular}


Tabel 4. Data Alternatif

\begin{tabular}{|l|l|l|}
\hline No. & Alternatif & Nama Alternatif \\
\hline 1 & $A_{1}$ & Honda Beat \\
\hline 2 & $A_{2}$ & Honda Vario \\
\hline 3 & $A_{3}$ & Honda CS1 \\
\hline 4 & $A_{4}$ & Yamaha RX King \\
\hline 5 & $A_{5}$ & Honda Beat Hitam \\
\hline
\end{tabular}

Tabel diatas akan diolah dan dianalisa menggunakan perhitungan algoritma Promethee untuk melihat perfomance dari algoritma terhadap data alternatif.

1. Algoritma Promethe

Sebelum memasuki tahap perhitungan dengan algoritma Promethee, penulis terlebih dahulu membuat rating kecocokan alternatif terhadap kriteria yang penulis dapatkan dari hasil observasi dan wawancara yang penulis lakukan sebelumnya. Berikut tabel rating kecocokan yang penulis dapatkan :

Tabel 5. Rating Kecocokan

\begin{tabular}{|c|c|c|c|c|c|c|c|c|}
\hline & & & & & Alte & atif & & \\
\hline Kriteri & & $\begin{array}{l}\text { Min } \\
\text { Maks }\end{array}$ & Bobot & $\begin{array}{c}\text { Honda } \\
\text { Beat }\end{array}$ & $\begin{array}{c}\text { Honda } \\
\text { Vario }\end{array}$ & CS1 & $\begin{array}{l}\text { Yamaha } \\
\text { RX King }\end{array}$ & $\begin{array}{c}\text { Honda } \\
\text { Beat }\end{array}$ \\
\hline & & & & & & & & \\
\hline BPKB & C1 & Maks & 0,25 & 5 & 5 & 5 & 2 & 5 \\
\hline STNK & $\mathrm{C} 2$ & Maks & 0,25 & 5 & 2 & 5 & 5 & 5 \\
\hline РАJAK & $\mathrm{C} 3$ & Min & 0,125 & 5 & 2 & 2 & 2 & 5 \\
\hline MESIN & C4 & Maks & 0,25 & 5 & 5 & 5 & 2 & 5 \\
\hline $\begin{array}{l}\text { Lama } \\
\text { Pemakaian }\end{array}$ & C5 & Min & 0,125 & 5 & 5 & 3 & 1 & 5 \\
\hline
\end{tabular}

Dalam menentukan tingkat kelayakan barang lelang menggunakan algorima Promethe, Penulis menentukan jenis-jenis kriteria yang akan dipertimbangkan. Dalam sistem pendukung keputusan menentukan tingkat kelayakan barang lelang pada kejaksaan negeri simalungun, instansi tersebut menetapkan kriteria-kriteria yang digunakan sebagai acuan dalam pengambilan keputusan yaitu BPKB, STNK, Pajak, Mesin dan Lama Pemakaian. Kemudian kelima kriteria tersebut di bandingkan satu per satu, yang dalam istilah Promethe.

2. Memberikan nilai kriteria dan alternatif

Memberikan nilai kriteria atau skor untuk masing-masing alternatif barang lelang. Proses penilaian kelayakan barang lelang dilakukan oleh pengambil keputusan sesuai dengan alternatif yang telah ditentukan. 
Tabel 6. Nilai Bobot Alternatif dari tiap Kriteria

\begin{tabular}{|l|l|r|c|c|c|c|c|c|c|c|}
\hline \multirow{2}{*}{ Kriteria } & \multirow{2}{*}{ Min Maks } & \multirow{2}{*}{ Bobot } & \multicolumn{5}{|c|}{ Alternatif } & \multirow{2}{*}{ Tipe Preferensi } & Parameter \\
\cline { 4 - 10 } & & A1 & A2 & A3 & A4 & A5 & & q & p \\
\hline C1 & Maks & 0,25 & 5 & 5 & 5 & 2 & 5 & 3 & & 2 \\
\hline C2 & Maks & 0,25 & 5 & 2 & 5 & 5 & 5 & 3 & & 2 \\
\hline C3 & Min & 0,125 & 5 & 2 & 2 & 2 & 5 & 5 & 1 & 2 \\
\hline C4 & Maks & 0,25 & 5 & 5 & 5 & 2 & 5 & 3 & & 2 \\
\hline C5 & Min & 0,125 & 5 & 5 & 3 & 1 & 5 & 1 & & \\
\hline
\end{tabular}

3. Hitung preferen indek

Indeks preferensi multikriteria ditentukan berdasarkan rata-rata bobot dari fungsi preferensi P. Berdasarkan tabel 3.6 maka untuk menghitung nilai selisih dari persamaan alternatiif sebagai berikut.

a. Persamaan untuk kriteria $\mathrm{C} 1$ menggunakan tipe preferensi 3 dengan ketentuan sebagai berikut:

- $\quad \mathrm{P}=2, \mathrm{P}=\mathrm{d} / \mathrm{p}$ jika $-\mathrm{p}<=\mathrm{d}<=$ p dan $\mathrm{a}<\mathrm{b}$ maka $\mathrm{P}=0$

- $\quad P=1$ jika $d<-$ p atau $d>$ p dan a $>$ b maka $P=d / p$ jika - p $<=d<=$ p

- $\quad$ Bobot $=0.25$

b. Persamaan untuk kriteria C2 menggunakan tipe preferensi 3 dengan ketentuan sebagai berikut:

- $\quad \mathrm{P}=2, \mathrm{P}=\mathrm{d} / \mathrm{p}$ jika $-\mathrm{p}<=\mathrm{d}<=\mathrm{p}$ dan $\mathrm{a}<\mathrm{b}$ maka $\mathrm{P}=0$

- $\quad P=1$ jika $d<-$ p atau $d>$ p dan a $>$ b maka $P=d / p$ jika - p $<=d<=$ p

- $\quad$ Bobot $=0.25$

4. Hasil Perangkingan

Hasil perangkingan dari proses metode promethee adalah sebagai berikut:

Tabel 7. Hasil Perangkingan

\begin{tabular}{|l|l|c|c|c|c|}
\hline \multicolumn{2}{|l|}{ Hasil Akhir } & & & & \\
\hline Alternatif & Leaving Flow & Entering Flow & Net Flow & Urutan \\
\hline A1 & Honda Beat & 0,188 & 0,156 & 0,031 & 2 \\
\hline A2 & Honda Vario & 0,188 & 0,313 & $-0,125$ & 4 \\
\hline A3 & Honda CS1 & 0,344 & 0,031 & 0,313 & 1 \\
\hline A4 & Yamaha RX King & 0,250 & 0,500 & $-0,250$ & 5 \\
\hline A5 & Honda Bead Hitam & 0,188 & 0,156 & 0,031 & 2 \\
\hline
\end{tabular}

Berdasarkan hasil diatas, dapat ditarik kesimpulan sementara yaitu:

a. Alternatif A3 menjadi alternatif terpilih.

b. Hasil perhitungan algoritma Promethe lebih real karena memiliki selisih nilai antar alternatif.

c. Algoritma Promethe sangat baik digunakan untuk melihat perangkingan alternatif. 


\section{HASIL DAN PEMBAHASAN}

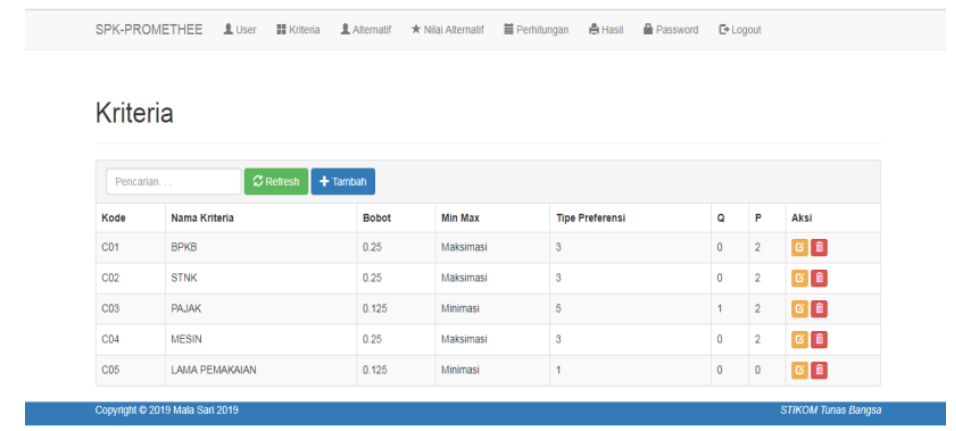

Gambar 7. Form Data Kriteria

Data kriteria ini untuk melakukan pengisian data, atau penyimpanan data sub kriteria.

a. Tampilan Form Data Alternatif

Form ini ditujukan untuk menyimpan data alternatif. Tampilan form alternatif dapat dilihat pada gambar 4.4. berikut:

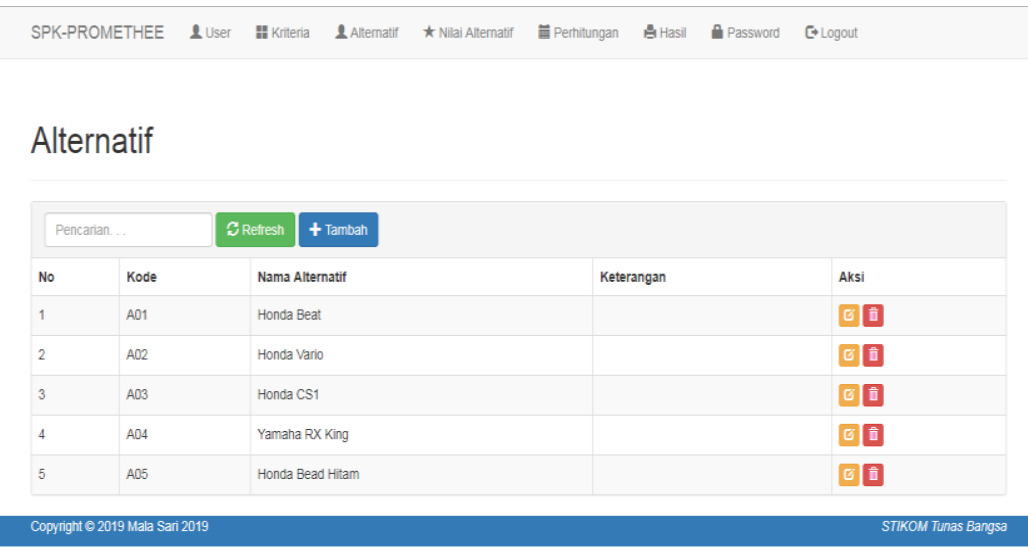

Gambar 8. Form Data Alternatif

Untuk melakukan pengisian data Nilai Alternatif, pengguna menekan tombol + dan melakukan isian sesuai dengan form yang telah ditentukan. Jika pengisian sudah selesai, pengguna menekan tombol simpan untuk melakukan penyimpanan data kembali. Setelah data diubah, klik tombol simpan untuk melakukan pembaharuan data. Untuk melakukan penghapusan data, pengguna memilih data yang ingin dihapus, kemudia menekan tombol icon X. Data akan terhapus sesuai keinginan pengguna sistem.

Laporan hasil perhitungan dapat ditampilkan dengan cara klik cetak, maka tampilan laporan hasil perhitungan dapat dilihat pada gambar 4.12. berikut: 


5/23/2019 Cetak Laporan
Laporan Hasil Perhitungan
\begin{tabular}{|l|l|l|l|l|l|}
\hline \hline Rank & Kode & Nama Alternatif & Leave flow & Entering flow & Net flow \\
\hline 1 & A03 & Honda CS1 & 0.3438 & 0.0313 & 0.3125 \\
\hline 2 & A01 & Honda Beat & 0.1875 & 0.1563 & 0.0313 \\
\hline 3 & A05 & Honda Bead Hitam & 0.1875 & 0.1563 & 0.0313 \\
\hline 4 & A02 & Honda Vario & 0.1875 & 0.3125 & -0.125 \\
\hline 5 & A04 & Yamaha RX King & 0.25 & 0.5 & -0.25 \\
\hline
\end{tabular}

\section{Gambar 9. Laporan Hasil Perhitungan}

\section{KESIMPULAN}

Berdasarkan uraian yang telah di paparkan bab demi bab dari skripsi yang penulis buat, penulis dapat menyimpulkan bahwa :

a. Sistem yang dibangun algoritma Promethe dalam menentukan tingkat kelayakan barang lelang pada Kejaksaan Negeri Simalungun merupakan sistem berbasis web dengan menggunakan aplikasi Macromedia Dreamweaver CS 6.0 dan MYSQL Server.

b. Hasil akhir yang diperoleh baik menggunakan perhitungan secara manual maupun secara komputerisasi menunjukkan hasil yang sama, yaitu alternatif $A_{1}$ yang terpilih sebagai alternatif terbaik yang paling layak mendapat rekomendasi barang lelang terbaik dalam menentukan tingkat Kelayakan Barang Lelang pada Kejaksaan Negeri Simalungun.

c. Bilangan real yang dihasilkan oleh perhitungan menggunakan algoritma Promethe akan mampu menampilkan selisih antar alternatif yang dibandingkan sehingga kemungkinan hasil yang diperoleh sama menjadi lebih kecil.

\section{DAFTAR PUSTAKA}

[1] R. A. Hutasoit, S. Solikhun, and A. Wanto, "Analisa Pemilihan Barista dengan Menggunakan Metode TOPSIS (Studi Kasus: Mo Coffee)," KOMIK (Konferensi Nasional Teknologi Informasi dan Komputer), vol. 2, no. 1, pp. 256-262, 2018.

[2] T. Imandasari, A. Wanto, and A. P. Windarto, "Analisis Pengambilan Keputusan Dalam Menentukan Mahasiswa PKL Menggunakan Metode PROMETHEE," Jurnal Riset Komputer (JURIKOM), vol. 5, no. 3, pp. 234-239, 2018.

[3] M. Masitha, D. Hartama, and A. Wanto, "Analisa Metode (AHP) pada Pembelian Sepatu Sekolah Berdasarkan Konsumen," Seminar Nasional Sains \& Teknologi Informasi (SENSASI), vol. 1, no. 1, pp. 338-342, 2018.

[4] S. R. Ningsih, D. Hartama, A. Wanto, I. Parlina, and Solikhun, "Penerapan Sistem Pendukung Keputusan Pada Pemilihan Objek Wisata di Simalungun," in Seminar Nasional Teknologi Komputer \& Sains (SAINTEKS), 2019, pp. 731-735.

[5] L. P. Purba, A. P. Windarto, and A. Wanto, "Faktor Terbesar Rendahnya Minat Ber-KB (Keluarga Berencana) dengan Metode ELECTRE II," Seminar Nasional Sains \& Teknologi Informasi (SENSASI), vol. 1, no. 1, pp. 369-374, 2018.

[6] N. Rofiqo, A. P. Windarto, and A. Wanto, "Penerapan Metode VIKOR Pada Faktor Penyebab Rendahnya Minat Mahasiswa Dalam Menulis Artikel Ilmiah," Seminar Nasional Sains \& Teknologi Informasi (SENSASI), vol. 1, no. 1, pp. 228-237, 2018.

[7] S. Sundari, S. M. Sinaga, I. S. Damanik, and A. Wanto, "Sistem Pendukung Keputusan Pemilihan Peserta Olimpiade Matematika SMA Swasta Teladan Pematangsiantar Dengan Metode Electre," in Seminar Nasional Teknologi Komputer \& Sains (SAINTEKS), 2019, pp. 793-799.

[8] S. Sundari, A. Wanto, Saifullah, and I. Gunawan, "Sistem Pendukung Keputusan Dengan Menggunakan Metode Electre Dalam Merekomendasikan Dosen Berprestasi Bidang Ilmu 
Komputer (Study Kasus di AMIK \& STIKOM Tunas Bangsa)," in Seminar Nasional Multi Disiplin Ilmu, 2017, pp. 1-6.

[9] A. Wanto and H. Damanik, "Analisis Penerapan Sistem Pendukung Keputusan Terhadap Seleksi Penerima Beasiswa BBM (Bantuan Belajar Mahasiswa) Pada Perguruan Tinggi Menggunakan Metode Simple Additive Weighting (SAW) (Studi Kasus : AMIK Tunas Bangsa Pematangsiantar)," in Seminar Nasional Rekayasa (SNTR) II, 2015, no. 2, pp. 323-333.

[10] A. Wanto and E. Kurniawan, "Seleksi Penerimaan Asisten Laboratorium Menggunakan Algoritma AHP Pada AMIK-STIKOM Tunas Bangsa Pematangsiantar," Jurnal Informatika dan Komputer (JIKO), vol. 3, no. 1, pp. 11-18, 2018.

[11] M. Widyasuti, A. Wanto, D. Hartama, and E. Purwanto, "Rekomendasi Penjualan Aksesoris Handphone Menggunakan Metode Analitycal Hierarchy Process (AHP)," Konferensi Nasional Teknologi Informasi dan Komputer (KOMIK), vol. I, no. 1, pp. 27-32, 2017.

[12] S. Pami, "SISTEM PENDUKUNG KEPUTUSAN PEMILIHAN KARYAWAN TERBAIK DENGAN METODE PROMETHEE (STUDI KASUS: PT. KARYA ABADI MANDIRI)," vol. 16, no. July, pp. 298-301, 2017.

[13] E. L. Amalia and D. S. Horma, "Sistem Pendukung Keputusan Pemilihan Dosen Berprestasi Menggunakan Metode Promethee," vol. 3, pp. 75-85, 2017.

[14] N. Azizah and S. Winiarti, "Sistem Pendukung Keputusan Seleksi Calon Karyawan Dengan Metode Promethee Studi Kasus Pamella Group Yogyakarta," Jurnal Sarjana Teknik Informatika, vol. 2, pp. 1061-1075, 2014. 